\title{
Freie Universität Berlin
}

\author{
Manfred Pfister
}

Travelling in the traces of...: The travelogue and its pre-texts

\begin{abstract}
:
Travelling is always a travelling in traces - looking for traces of past cultures or following the traces of previous travellers. These traces can be material or textual, visual, performative or mnemonic. In some of the best of $20^{\text {th }}$ travel writing, such quests for traces do, however, take an inward and self-reflective turn in which travel writing becomes a form of self-writing and self-staging.

In my essay, I will survey this development from the eighteenth century to the present, beginning with Grand Tour accounts of journeys to Italy to then focus on modernist and postmodernist travel writing. This will take us not only to Etruscan Places with DH Lawrence or Patagonia with Bruce Chatwin, to Asia Minor on Alexander's Path with Freya Stark or to the Caribbean with Amryl Johnson but back into these writer's lives, their deepest memories and desires. What should emerge in my readings is how writing the 'Other' can become a way of writing the Self.
\end{abstract}

Biographical note:

Manfred Pfister was Professor of English at the Freie Universität Berlin and is a member of the Berlin-Brandenburgische Akademie der Wissenschaften. He was co-editor of the Shakespeare Jahrbuch and Poetica and author of Das Drama. Theorie und Analyse (Munich, 1982; Engl.: CUP, 1988) and The Fatal Gift of Beauty: The Italies of English Travellers (1996). Among his more recent book publications are Laurence Sterne (2001), A History of English Laughter (2002), Performing National Identity: Anglo-Italian Transactions (2008), William Shakespeare's Sonnets, for the First Time Globally Reprinted. A Quatercentenary Anthology (2009), Dialoge zwischen Wissenschaft, Kunst und Literatur in der Renaissance (2011), Heroen und Heroisierungen in der Renaissance (2013) and editions of Bruce Chatwin's In Patagonia (2003), Samuel Butler's Notebooks (2005), Shelley's Zastrozzi (2009 and Sir Thomas Browne's Urne Buriall and Selected Writings (2014). He is also a translator and as such one of the German voices of Robert Lowell (1982) and Ezra Pound (Die Cantos, 2012). His most recent book is on Literary Analysis and Linguistics (2017). Since his retirement he spends half of his life in the Italian Maremma.

$\underline{\text { Keywords: }}$ traces - travel writing - romantic - modern - postmodern 
My title 'Travelling in the traces of...' might suggest that there is a mode of travelling that does not follow any traces. Such a distinction between 'travelling in traces' and 'traceless travelling' appears to be plausible enough and 'natural' at first sight, and many travellers -even more travel writers - would subscribe to it emphatically.

In 1991, just embarked upon my studies of travelogues, I invited a group of British travel writers to a remote Austrian castle to discuss their art with a few German academic critics. We soon became aware of the extent to which the pathos of travelling in unchartered; traceless lands can be crucial to self-understanding as travellers and travel writers, and how vehemently we were prepared to defend the idea. For a prominent travel writer such as Geoffrey Moorhouse, who had given the steeply Nietzschean title of The Fearful Void to the travelogue about his camel ride and walk of more than 3,600 miles across the Sahara in 1972/73 (Moorhouse 1974), it appeared as downright well-poisoning to his ethos as well as his poetics of travel writing when a bunch of smart alecky academic - and, even worse, German! - armchair travellers tried to convince him that a 'fearful void' is not uninscribed with trace.

Moorhouse and his ilk invoke - in the high pathos of exploring untraced, 'virginal' lands yet undescribed by previous travellers - the eighteenth-century poetics of the travelogue when it began to develop a sense of its own identity as a genre dedicated to 'autopsy', i.e. personal observation, seeing for oneself. As such, it claimed to write only what the traveller had seen with his or her own unblinkered eyes, and ideally only that which others had not witnessed previously or had done so only in ways different from their own. Under these premises of autopsy, the travelogue is a genre of 'negated intertextuality', of negated traces (Pfister 1993: 110-11).

Accordingly - and often for colonialist reasons - travel writers like to imagine the alien, the strange, the other as a tabula rasa, an empty slate, without traces of prior inscriptions. The other, as tabula rasa, does not show inscriptions of the past, nor does the traveller wish to know about previous texts overwriting it. No wonder that the explorer-traveller Alexander von Humboldt carefully erased almost all traces of 'pre-texts' or 'pre-scriptions' in the published versions of his report (see Pratt 1992: chap 6).

Such premises did not apply only to accounts of journeys to remote lands outside Europe; they were also operative, even if in somewhat changed form, in accounts of journeys within Europe. Here, since the eighteenth and increasingly so in the nineteenth century, travel writing - to the extent to which it considered itself a literary practice - aligned itself with an emphatically individualistic travelling which distinguished itself in its class-bound cultural elitism from the mere tourism of ever greater masses who launched upon package tours on beaten tracks (see Buzard 1993; Pfister 1999: 469). One senses this already in Laurence Sterne's Sentimental Journey (1768), in particular in his ridicule of the Grand Tourists on their beaten tracks, seeing nothing with their own eyes but only through the lenses of their guide books or ciceroni (travel guides) re-enacting in the vapid rituals of mass tourism the highly canonised sights or videnda, instead of reading and following their own traces. And it is also felt in Sterne's particular appreciation of journeys across empty 
and yet undescribed lands, which become a stimulus or challenge to his own individual perceptions and emotions (see Sterne 1984: 28).

Literary travel writing in the age of mass tourism opts for autopsy, even if for reasons different from those of the explorers' accounts; it opts for feeling one's own spontaneous emotions, seeing with one's own eyes what others - certainly not all, but few and ideally none - have not seen and described before. With that it opts for a mode of travelling that does not follow the traces of beaten tracks and for a mode of travel writing that does not revolve in the grooves of a fixed soundtrack but marks its own tracks.

However, even texts that define themselves categorically in such terms do not actually manage to realise this programme to perfection. No erasure of traces is ever total: erasing traces always leaves behind traces, the traces of traces, as it were. To use an example from another art form, not even in Robert Rauschenberg's 'Erased de Kooning Drawing' (1953) is Willem de Kooning's work removed without leaving traces; one might even argue that the 'erasure' in Rauschenberg's title highlights de Kooning's underlying drawing as being invisible and visible at the same time (see Rauschenberg 1980: 262f). Of course, even in periods in which travelogues predominantly followed the 'traceless' paradigm, some travellers staged their journeys as a search for traces. One might, perhaps, construct a sliding-scale typology of travel writers between those who blur, obliterate or erase traces and those who highlight their reading of them. For travel in a traceless void uninscribed with textual or other traces, there would be no place on such a sliding scale; it is an ideological chimera and accordingly belongs for us to trace-blurring. And when it comes to that, travel writing cannot be based on autopsy in the strict and exclusive sense of the word: even the allegedly autoptic glance is inscribed with the traces of previous texts and images.

At this point, perhaps, I should explain what I mean here by 'traces' in which one can travel.

\section{Tracing traces}

To begin with, I would distinguish between material and textual traces. The first are the semantic protoype 'trace': traces in the sand or field, dug by our predecessors, relics left by them and markers or signposts set up for guidance. The history of travel writing offers impressive examples of searching for traces in this literal sense, for instance Henry Morton Stanley's How I Found Livingston (1872), the account of his journey across Africa in search of the lost explorer. In comparison, textual traces play a much more pervasive role for organising the routes of travels and travel writing, regardless of whether they follow the written pretexts or deliberately avoid them. Among these textual traces are, most prominently, maps, representing in a conjunction of words and images the observations and insights of previous travellers. Even Columbus set out with maps on his journey across untraced waters, albeit misleading ones, and even Graham Greene's programmatically entitled Journey Without Maps (1963) into Dark Africa and, at the same time, into the inner darkness of his own subconscious, could not really do without maps, offering one to the reader on the opening pages of his book (Greene 1978: 10f). 
Maps, together with guide books and travelogues, constitute the ensemble of textual representations of the other which travellers carry along with them - be it materially as their travel companions or stored in their memory - to follow the roots they propose themselves. Thus, for instance, classic Grand Tour guide books, as well as those pertaining to modern tourism, leave their invisible traces across the foreign territory, traces that lead from one sight highlighted with an array of stars to the next, while more literary travel books delineate their traces outside the beaten tracks. The more demanding travellers seek to liberate themselves from such popular touristic pre-texts or pre-scriptions and prefer for textual guidance on individually self-chosen tracks - older travelogues or other historical sources such as the works and biographies of great poets and artists. For this, the modern book trade offers entire series and collections to accompany 'alternative' travellers to all the major touristic destinations of the world. To illustrate the variety of pre-texts available, let me mention a few examples of publications which relate to one of my own not only academic - preferences: travelling in traces across Italy.

One of the first literary travellers to Italy, Shakespeare's contemporary Thomas Coryate, already described himself as a 'tombstone traveller' in his Crudities (1611), tracing the tombs and birthplaces of the great (Coryate 1611 [1978]). With Romanticism, the auratic traces of the lives and deaths of the English poets in Italy - Keats, Byron, Shelley and many more - became places of literary pilgrimage. Before that, Joseph Addison in his Remarks on Several Parts of Italy (1701-1703) had followed the traces of classical Roman poetry across Italy, 'travelling through the poets, and not through Italy', as Horace Walpole put it cuttingly in a letter (qtd in Pfister 1996a: 467). Indeed, Addison takes note of rural or scenic beauty only where he found it already described in Virgil's or Horace's poems. His intertextual method 'to compare the natural face of the country with the landscapes that the poets have given us' turns his Italian journey into a journey across the classical reference library he travelled with and often leads him to way-out places, which he puts on the map of future travellers with his poetic description. In some cases, a single verse suffices to put generations of them on the track. For instance, Milton's epic simile for the hosts of fallen angels in Paradise Lost (I, 302-4) - 'leaves that strew the brooks /In Vallombrosa...' - led hosts of British travellers and tourists since the eighteenth century in search of education on the 'Milton Trail' to the remote monastery in Vallombrosa outside Florence and triggered an entire tourist infrastructure and industry (see e.g. Doward 2017).

The pre-texts involved are by no means always literary. This applies particularly to what one might call 'archeological' travels in a wide sense of the word. Such travelling is quite literally a search for traces, 'a travelling in traces', as my title has it: it looks for and follows traces of a lost world, greater or more authentic than the present, and often employs older historical texts for a search grid. Thus, for instance, Norman Douglas in his Old Calabria (1915) looks for the traces of an older, happier Italy and follows in this, among others, the traces of the great historian and archaeologist François Lenormant, who crossed the Italian South on his quest for the Magna Graecia of pleasure-seeking and life-affirming sybarites and for other pre-Italic sediments hidden under the surface, as recorded in his $A$ travers l'Apulie et la Lucanie (1883) (Duncan's appraisal and critique of his pre-traveller Lenormant foregrounds the dialogue between the two searchers for traces in the final 
chapter; see Douglas 1962: 332f). Here, as in the journeys in search of the mysterious, largely forgotten culture of the Etruscans in Elizabeth Caroline Hamilton Gray's Tour to the Sepulchres of Etruria (1840) or George Dennis' The Cities and Cemeteries of Etruria (1848) (see Pfister 1996a: 481 and Wellard 1973), studying the texts of previous travellers can lead to costly and adventurous journeys across out-of-the-way lands and to an arduous search for traces in which the traveller checks his pre-travellers' reading of traces against his own autoptic observations.

When DH Lawrence in 1927 on his last journey also searched for Etruscan Places (1932), he tried to liberate himself as much as possible from all book learning and follow instead the memory traces inscribed deep in his own subconscious of life-affirming - because death-accepting - modes of being. Such mnemonic traces are the third category next to material or textual traces I wish to itemise. Though they are also woven into intertextual nets, the textual inscriptions lie so deep that they cannot be traced back to single definite texts. Mind you, memory traces in particular are generally not marked by textual or material traces but by the traces of images and performances: internalised dream or memory images which - consciously, half-consciously or unconsciously - give the desires of travellers their orientation; remembered performances which are re-enacted bodily and kinesthetically by the traveller, either in the ritualistic repetition of following the beaten tracks and sightseeing programs of tourism, or religious and cultural pilgrimages. It is one thing to travel like Weimar's Privy Councillor Goethe as a Grand Tourist in a luxurious coach down the Italian peninsula (1786-88), and another to walk the whole way on foot, as Johann Gottfried Seume was to do in his Spaziergang nach Syrakus (1802). The latter is, in the face of the political turmoil in the Italy of the early nineteenth century and the athletic challenge involved, an astonishing performance. Moreover, it is a performance that evokes quite different memory images and discovers quite different traces from Goethe's; in Seume's case political and economical ones rather than Goethe's canon of cultural memories. Seume himself pinpointed this in the preface to Mein Sommer 1805: 'Who walks generally sees more anthropologically and cosmically than he who is driven in a coach.... As soon as you sit in a carriage, you are at once some degree remote from common humanity' (my translation from Klingenberg 1965: II, 7 \& 8).

But Goethe's experience of Naples, recalled in his Italian Journey many years after the event, also demonstrates the importance of memory images and performative traces reenacted with his own body. As to texts, he had read enough of them before, from the Italian notebooks of his own father to Johann Jacob Volkmann's encyclopedic Historical-critical News of Italy (1770-71) and he had studied carefully the collection of maps, etchings and views of cities and natural sights he carried with him for perusal on the spot to be able to follow the traces in detail and check the textual and visual representations against what he saw with his own eyes to get as close as possible to the object in his own writing. Still, his writing of Naples in the end left behind the cultural workload of classical education that had weighed upon him during his first Roman sojourn. What counts now, confronted with the temple of Paestum, south of Naples, are not classical pretexts, but the memory traces of an initially off-putting and 'totally alien word', the Urbilder of an archaic world that 'make alive to him for the first time ever the words of the Odyssee' (my translation from 
Goethe 1964: XI, $219 \& 323)$. And beyond that, the strenuous and adventurous mounting of the crater of Vesuvius makes him follow physical traces, which lead him back to the prehistory of the world and stimulate again his phantasies of an Urpflanze, the primordial plant, before the division of plants into separate species (324). Similarly, his close contacts with the world of the pleasure-loving lower-class lazzaroni of Naples evoke in him memories of a life happier and more sensual than the modern life in the North, a life in which 'nobody works for a living alone, but for joy, and in which work itself is a pleasure' (338). Once transformed like that in the alembic of the collective body of the Napolitan populace, Goethe finally manages to leave far behind all the prejudices held by earlier travellers who arrogantly presumed to sum up these creative followers of a dolce far' niente as 'thirty to forty thousand good-for-nothing idlers of Naples (332).

The search for traces of buried memories is worth a separate category if only because it plays such an important role in modernist travel writing. Bruce Chatwin's memories of a prehistorical piece of prontosaurus skin in his grandfather's drawing-room showcase, which had already stimulated his phantasies as a boy, are the postmodern locus classicus for this (see Pfister 1996b: 253-267). The search for traces of this lost material relic will guide him not only to a lost paleoontological past and other traces in the European cultural memory - the archives of images and texts about Patagonia - but also to his own childhood. As WG Sebald, the other great searcher of traces and admirer of Chatwin, remarked in an essay on Chatwin, his 'paths towards the end of the world turn into expeditions in search of a lost boy' (my translation from Sebald 2002: 140; see also Pfister 2003: 357-359).

\section{Modern travel writing and the search for traces: four varieties}

With Chatwin I have reached contemporary travel writing and have already anticipated my main point about modern travel writing: in it, the literary search for traces becomes in a new way thematic and problematic at the same time. The emphatically modern literary traveller frequently stages himself or herself as searching for and following traces and foregrounds that motivation and orientation in often complex, problematic and aporetic narrative constructions. (My argument here links up with two earlier studies of mine on the modernisation and postmodernisation of travel writing: (see Pfister 1996b: 253-267) and Pfister 1999: 462-487). I shall try to exemplify this in the following with reference to four particularly significant varieties.

As an example of the first variety, the archeological search for material traces, I choose a text that highlights traces or tracks already in its title: Freya Stark's Alexander's Path (Stark 1988). This may not be the best-known book by the famous orientalist traveller, but in this context Alexander's Path is particularly significant, because here Stark renounces from the beginning the conventional image of so many female travellers of her times travelling aimlessly for the sake of travelling and defines instead her journey from the very beginning as a precisely-targeted project: to follow and re-enact in all detail the track and traces of Alexander the Great's army across Asia Minor. For this she does not only turn to the classical and typical sources on Alexander's campaign - Arrianos' Anabasis, and the oftencontradictory accounts of more recent travellers - she also checks their information 
autoptically and measures distances by counting her own steps or the hours travelled. We witness how her glance moves constantly between text and landscape to work out some congruence between the archeological or geological and the textual traces, and she even finds time to compare the traces of Alexander's path with the inscriptions of contemporary Turkey on its way to a modern nation state. In her dialogue with the polyphonic pre-texts of classical and modern historians and travellers, she always prioritises her own sensual experiences and, in cases of divergence, takes to task with sportive arrogance the exclusively male authorities: 'They were splendid young men, however erratic their timetable may have been up the hill' (Stark 1988: 183).

Why all this physical and mental effort to establish Alexander's traces with such precision? Was it learnt pedantry or a know-it-all manner, or did she need a scholarly pretext to give the dignity of serious purpose to her wanderlust or passion for adventure? For an answer, one has to take into account her fascination with him in whose traces she travels and with where they lead her to: the Great Alexander, 'the most dynamic being that the world has perhaps ever known' (230), and his vision of an oikumene of occident and orient, which has its point of departure in the Persian campaign and will end in India and fail there. It is for this that her at-first-sight so successful quest for Alexander's traces ends so elegiacally in the identification of the failure of his dream with her own failure:

So the young dream died, of the brotherhood of men.... That, I thought suddenly, is why I am so unhappy. I have failed this brotherhood. I should have stayed.... Alexander's vision ended and was lost for over two thousand years; and we, who are dreaming it again, look extremely like failure at the moment... (225)

Her dream of a 'West-Eastern Divan' - the problematic imbrication of which in her lifelong service for the British Empire we need not discuss here - began in her childhood. And it began with a book: 'An imaginative aunt who, for my ninth birthday, sent me a copy of the Arabian Nights, was, I suppose, the original cause of the trouble' (Stark 1952: 9).

For Fiona Pitt-Kethley also the archeological search for traces began in early childhood with mythological stories of the sooth-saying sibyls, which her mother had told her and which then sent the adult writer on a quest for the traces of sibyls to Rome, Tivoli, Cumae, Avernus or Marsala in her Journeys to the Underworld (Pitt-Kethley 1988: 1f). The selftaught archaeologist intends to experience in her own body and in situ, in the caverns and grottoes of the sibyls, their mode of living. With that, her explorations into the underworld do not only serve the verification of archeological traces but also turn into a quest for the deeper and hidden origins and sources of her own power - her feminist quest for the selfpossession and wisdom of witches and prophetesses, in whom she sees her own role of poetess and free-booting sexual adventuress prefigured. Thus, her journey does not only lead her back to an archeological and mythical past but also into the Italian present, in which she tests in ever bolder experiments the myth of the sexually potent Latin Lover to reveal the inhibitions, the anxieties and the fears of emancipated women from the North behind the macho façade. This frequently culminates in an erotic carnival, when she shortcircuits the modern with the classical world, for instance the sauna bathers of Baiae (the 
Roman luxury spa near Naples) with modern tourists and their guides, who together reenact what the classical texts describe:

It's not often you get the chance to do it exactly where the poshest Romans did it. The Caesars might have done it here, Antony and Cleopatra, Virgil, Horace, Martial ... who knows who ... Now how could this perfect stranger have guessed I have a kink about sex in historic locations? (I once had it off in the Coliseum.) When in Baia do as the Romans did. (Pitt-Kethley 1988: 25)

With the second variety, texts, and in particular literary texts, play an even more important role. What I have in mind here is travel writing as biography or even more pointedly, biography as travel writing. The research for a biography and the writing of it always involves a certain amount of travelling in the life traces of the biographee, even if normally the biographer's travelling is largely erased in the final text. More recently, however, in an increasing number of cases, we find literary biographers who make the account of their own journeys in search of links between the life and the works of the biographee their main theme or principle of narrative organisation. The first instance of this is, to my knowledge, AJA Symons' Quest for Corvo (1934), subtitled 'An experiment in biography'. The story it tells is less that of the life and works of the mysterious Fin-de-siècle writer Frederick William Rolfe (alias 'Corvo') in chronological sequence, and more the sleuthing story of Symons' own painstaking attempts to unravel the traces of Corvo in dark and strange places in Venice and Rome and to bring the mysteries of his decadent life to light. What is emphatically 'modern' about this experiment in biography is that it abandons the conventional claims of biographers to offer the the truth, the whole truth, on the life and works of an artist and puts into doubt any such claims.

Since then, this mode of narration has become an established subgenre in biography. An influential model for this was provided in 1985 by Richard Holmes in a collection of biographical sketches titled programmatically Footsteps: Adventures of a Romantic Biographer and introduced as 'a kind of pursuit, a tracking of the physical trail of someone's path through the past, a following of footsteps' (Holmes 1986: 27; see also 67, where he writes about the biographer's necessary 'self-identification' or 'self-projection' while searching for traces of his biographee 'in landscapes, buildings, photographs and above all the actual trace of hand writing on original letters and journals'). Quite a number have followed him since then on such traces, among them Nicholas Rankin with Dead Man's Chest: Travels After Robert Louis Stevenson (Rankin 1987; further relevant titles are referred to in Pfister 1993: 127-129). Stevenson was already the subject of the first chapter of Holmes' Footsteps, and both travellers in biography deal with an author who not only travelled much himself but had also written travelogues. Stevenson's classic travel book, Travels with a Donkey in the Cévennes (1879), encouraged both biographers to reenact his journey, book in hand, following his footsteps as closely as possible. Holmes had done that already in 1964 as a young man and many years later enriched his original travel notes after having read Stevenson's own diary published in 1978 for the first time (Stevenson 1978). Here also, the textual and material traces to be unravelled are closely intertwined, and the trace is no longer one across the French Cévennes alone, but one that dives into the psychology of the author and his secret dialogue with his far-away beloved, 
Fanny Osbourne. For such a reading it was not necessary to engage once again on this strenuous walk, which, with the centenary of Stevenson's book, had become a touristic ritual for British lovers of literature and the South of France. Rankin spared himself the trouble and skipped the $227 \mathrm{~km}$ hike across the mountains of the Dordogne altogether when he embarked in the 1980s on following the trajectory of Stevenson's life from Edinburgh to Samoa. By now, after all, the trace had turned into a well-marked track described in an Anglo-Fremch guide book, Sur les traces de Stevenson, and the London-based Waymark Holidays Company organised guided hikes for hundreds of tourists effacing all original traces (Rankin 1987: 114-16).

As much as such biographical travelling in the traces of authors' lives challenges the traditional claims of literary biography to offer a transparent and chronologically ordered account, it remains essentially committed to the conservative ethos of the genre, its aim of revealing the true nexus of l'homme et l'œuvre. For more radical innovations, one has to look out for fictions which undertake their reading of traces unprejudiced by the conventional positivism of biography. A brilliant case in point is, for instance, Julian Barnes' Flaubert's Parrot (1984), the novel about a dentist and amateur scholar from North England who sets out for Normandy to identify on the spot the one and only stuffed parrot that had inspired Flaubert in writing his 'Un cœur simple' (1877). In spite of - or rather because of - the utmost rigour and precision of his researches in situ, Barnes ends up not with one, but with an ever increasing number of plausible candidate until his failure to identify the true traces finds an even more disturbing echo in his failure to fathom the memories of his wife and her death.

Travelling in traces often takes the form of a quest: the trace leads to a destination or goal and this turns the search for traces into a teleological project, regardless of whether it reaches its end or fails. The narrative model of a quest is, from its origins in classical and medieval epic poetry, charged with the elevated cultural prestige of a medium making and representing a society's highest and ultimate aspirations. What one is struck with, however, is that postmodernist travel writing frequently employs the quest model to play disrespectful games with its cultural dignity. This is my third variety, in Bakhtinian terms dear to theories of postmodernism, the carnivalisation of travelling in traces. We have found elements of this already in Chatwin's and Pitt-Kethley's quests ending in disillusioned letdowns.

A particularly clear example of this is William Dalrymple's 1989 account of his journey from Jerusalem to China. Its title already aims very high indeed: In Xanadu: A Quest alludes to Coleridge's celebrated poem 'Kubla Khan', in particular its first line 'In Xanadu did Kubla Khan', as well as to Lowes' classic in source studies, The Road to Xanadu, and beyond that to a great tradition of European journeys to, and phantasies about, China, first and foremost Marco Polo's medieval Milione. It is in Marco Polo's traces that Dalrymple travels - not with the same meticulous precision with which Freya Stark or Richard Holmes had re-enacted the journeys of their pre-travellers - but insouciant about geographical or historical details. Dalrymple follows Marco Polo's path showing little interest in how he had read the culturual traces at the various stages of his journey, being interested alone in his own often grotesque adventures en route, which he plays off with comic gusto against 
the high-seriousness of his pre-traveller. The performative difference between their ways of travelling debunks Marco Polo's meraviglia del mondo thoroughly, beginning with the vial of sacred oil, which Dalrymple, like his medieval forerunner, carries from Christ's burial chapel in Jerusalem to China - only his modern oil does not burn miraculously forever and the lamp has to be refilled continuously from a banal can of sunflower oil and an equally commonplace plastic flask from the Body Shop. And unsurprisingly, the end of his quest proves a letdown or flop: he never meets Marco Polo nor reaches Marco Polo's or Coleridge's China: 'Our vision of Xanadu was nearer the heath scene in Lear than the exotic pleasure garden described by Polo’ (Dalrymple 1989: 298).

Such carnivalesque games with funny discrepancies between a canonical pre-text and the trivial experiences of one travelling in its traces in the cultural memory and in the real world has also caught on significantly recently. Let me mention briefly just one: Tim Moore's Continental Drifter: Taking the Low Road with the First Grand Tourist (Moore 2001). The 'first grand tourist', in whose traces Moore travels here, is Thomas Coryate, whose account of his strenuous walks across Northern Italy to Venice (1611) had set the agenda for many later Grand Tourists. Moore, however, does not walk it but ludicrously travels in a period Rolls Royce, the eccentricities and susceptibilities of which occupy him more than the literary quest along the inserted texts by Coryate and the Grand Tourists of the $17^{\text {th }}$ and $18^{\text {th }}$ century. He starts out on his journey fully convinced that his model is a 'grand bore' but his attitude to his forerunners changes gradually, and in the end he is no longer so sure that he has really won, as he thought at the beginning, 'all [his] running battles with Coryate' (Moore 2001: 15 \& 358).

All the travelling in traces I have considered so far in the context of my typology of modern travel writing were, in the language of colonial passages, 'voyages out', not 'in', i.e. away and not towards the traveller's own self or center of existence. It is the latter orientation, however, on which my fourth variety is normally based, travelling in mnemonic traces. My example is, not by chance, a female travelogue: Amryl Johnson's Sequins for a Ragged Hem (Johnson 1988; I am indebted here to Döring's perceptive reading in Döring 2002: 45-47), the account of her journey looking for traces that lead her back to her own origins and childhood, the account of a homecoming or, to use a good old Homeric word in order to emphasise the mythical resonance of it, a nostos, here the return of the black British writer from Trinidad to her Caribbean home. As such, her journey undermines the colonial 'voyage in' and 'voyage out', to start with, for as a return to her origins it is a voyage in, and as a journey away from her residence in exile as a naturalised British citizen it is at the same time a voyage out. Correspondingly unstable is the traveller's perspective, which oscillates between that of a tourist sightseeing in the (ex-)colonies, a migrant without a fixed abode or centre of life, or an island-born Trinidadian.

The journey Johnson narrates is already her second home journey; the first, a year before, had been overshadowed by the shock received immediately after arrival, her discovery that the deepest material trace of her memories, the house in which she was born, had been knocked down a couple of days before. The nostalgic desire to tread again in the footsteps of her childhood and to re-enact them in a commemorative performance - 'Heel to toe within every footprint, matching the outlines until I was back on that one road. The same I 
had travelled' (Johnson 1988: 12) - this nostalgic desire finds no fulfilment. The traces she follows on her second journey and learns to read are mnemonic traces, which go deeper than the autobiographical memories of childhood. These are embedded in yet deeper, halfburied sediments of cultural memory, memories of the Middle Passage and slavery in the sugar plantations of the Caribbean. On the island of Tobago a monumental iron wheel, recording the sugar plantations and the slaves' suffering, becomes 'the postcolonial turning point of her entire passage, the point from where the scars of history inscribed on Caribbean landscapes can be retraced so that her tour turns from touristic travelling into a rite de passage of personal redefinition' (Döring 2002: 47). Only now, the personal home-coming, the encounter with her mother, can take place, and it is with this that the book ends, not with her return to England.

This nostos, leading back to the mother, does no longer depend on textual traces or leave them behind. The classical texual foil to her 'going to the mothers' (to an origin or Heimat culturally encoded in maternal terms) in Goethe's Faust II (act I, verse 6265ff) is here subsumed under a female transcription, which refuses the pleasures of a nostalgic yearning for a place outside history, for a Heimat as a prelapsarian 'place of innocence' (see Ecker 1997: 31).

I wish to conclude with a text in which the mnemonic traces, highlighted already in the title, are particularly rich, although they converge on one place: Orhan Pamuk's wonderful Istanbul: Memories of a City (2005). Pamuk, travelling peripatetically in his own city, is a searcher for, and a reader of, traces if ever there was one: the cultural traces left by the city's Greek, Byzantine, Jewish, Armenian, Anatolian, Ottoman and modern Turkish populations, the traces inscribed upon the city by travellers from the West such as Nerval, Gautier or Flaubert, and, last but not least, the traces of his own childhood in Istanbul. His 'Memories of a City' evoke both his own memories of Istanbul and Istanbul's memories of its own past. His book is therefore a double, interconnected quest for Istanbul and for his own identity. By tracing the one he traces the other, as he realises late in his book: 'I have described Istanbul when describing myself, and described myself when describing Istanbul' (Pamuk 2005: 265). And in the end his quests for origins and identity 'come full circle, for anything we say about the city's essence, says more about our lives and our own states of mind. The city has no centre other than ourselves' (316).

Nor has the world. This is, indeed, where all the traces the best travellers follow end.

\section{Works cited}

Buzard, J 1993 The Beaten Track: European Tourism, Literature and the Ways to Culture 1800-1918, OUP, Oxford

Coryate, T 1978 [1611] Coryats crudities, Scholar Press, London (facsimile of 1611 edition printed by William Stansby, London)

Dalrymple, W 1989 In Xanadu. A Quest, Collins, London

Döring, T 2002 Caribbean-English Passages: Intertextuality in a Postcolonial Tradition, Routledge, London 
Pfister Travelling in the traces of...

Douglas, N 1962 Old Calabria. With an introduction by John Davenport, Penguin, Harmondsworth

Doward, J 2017 'When Milton met Galileo: the collision of cultures that helped shape Paradise Lost', The Guardian (20 August): https://www.theguardian.com/books/2017/aug/20/john-milton-paradise-lost-galileocollision-of-cultures-bbc-documentary

Ecker, G 1997 “"Heimat”: Das Elend einer unterschlagenen Differenz', in G Ecker (Hg), Kein Land in Sicht. Heimat - weiblich?, Fink Verlag, München: 7-31

Goethe, JW von 1964 Italienische Reise, in Herbert von Einem/Erich Trunz (Hg), Goethes Werke, 6 Aufl., Christian Wegner, Hamburg

Greene, G 1978 Journey Without Maps, Penguin, Harmondsworth

Holmes, R 1986 Footsteps: Adventures of a Romantic Biographer, Penguin, Harmondsworth

Johnson, A 1988 Sequins for a Ragged Hem, Virago, London

Klingenberg, A \& K-H (eds) 1965 Seumes Werke in zwei Bänden, $2^{\text {nd }}$ ed, Aufbau-Verlag, Berlin

McClintock, FL 1998 The Voyage of the Fox in the Arctic Seas: A Narrative of the Discovery of the Fate of Sir John Franklin and His Companions, ed Michael Hulse, Köln

Moore, T 2001 Continental Drifter: Taking the Low Road with the First Grand Tourist, Abacus, London Moorhouse, G 1974 The Fearful Void, Hodder \& Stoughton, London

Pamuk, O 2005 Memories of a City, trans M Freely, Faber and Faber, London

Pfister, M 1993 'Intertextuelles Reisen, oder: Der Reisebericht als Intertext, in H Foltinek (ed), Tales and 'Their Telling Difference': Zur Theorie und Geschichte der Narrativik. Festschrift zum 70. Geburtstag von Franz K. Stanzel, C Winter, Heidelberg: 109-132

(ed) 1996a The Fatal Gift of Beauty: The Italies of British Travellers. An Annotated Anthology,

Rodopi, Amsterdam

$1996 \mathrm{~b}$ 'Bruce Chatwin and the Postmodernization of the Travelogue', Literature, Interpretation, Theory 7: 253-267

1999 'Robert Byron and the Modernisation of Travel Writing', Poetica 31: 462-487

2003 'Nachwort', in B Chatwin, In Patagonia, ed Manfred Pfister, Reclam, Stuttgart: 353-377

Pitt-Kethley, F 1988 Journeys to the Underworld, Chatto \& Windus, London

Pratt, ML 1992 Imperial Eyes: Travel Writing and Transculturation, Routledge, London

Rankin, N 1987 Dead Man's Chest: Travels After Robert Louis Stevenson, Faber and Faber, London Rauschenberg, R 1980 Werke 1950-1980, Staatliche Kunsthalle, Berlin

Sebald, WG 2002 'Das Geheimnis des rotbraunen Fells', in HJ Balmes (ed), Chatwin's Rucksack. Portraits, Gespräche, Skizzen, Fischer, Frankfurt: 133-142

Stark, F 1952 The Valleys of the Assassins and Other Persian Travels, Penguin, Harmondsworth 1988 Alexander's Path: A Travel Memoir, Overlook, Woodstock NY

Sterne, L 1984 A Sentimental Journey, ed I Jack, OUP, Oxford

Stevenson, RL 1978 The Cévennes Journal: Notes on a Journey through the French Highlands, ed G Golding, Mainstream Publishing, Edinburgh

Wellard, J 1973 The Search for the Etruscans, Saturday Review Press, London 